\title{
Purification and Characterization of IgM-like Immunoglobulin from Turbot (Scophthalmus maximus L.)
}

\author{
By H. Kofod, K. Pedersen, J. L. Larsen, and K. Buchmann
}

Department of Veterınary Microbıology, Sectıon of Fish Diseases, Royal Veterinary and Agricultural University, Frederıksberg, Denmark.

\begin{abstract}
Kofod, H., K. Pedersen, J. L. Larsen and K. Buchmann: Purification and characterization of IgM-like immunoglobulin from turbot (Scophthalmus maximus L.). Acta vet. scand. 1994, 35, 1-10. - A total of 40 turbot (Scophthalmus maximus) were immunized 3 tımes durıng a 3 months perıod usıng DNP-HSA whereafter serum samples were collected and pooled. Specific ımmunoglobulıns (Ig) were affınity purified on an agarose column with immobilized DNP-BSA and further purified by gel filtration whereafter monospecific rabbit anti Ig serum was generated. Size exclusion chromatography and non-reduced SDS-PAGE indicated a MW of 8-900 kDa of the dominant antigen binding proteins from turbot serum. Reduced SDS-PAGE showed this fraction to be composed of disulphide linked heavy and light chains with MWs of 79 and 27-29 kDa, respectıvely, indicatıng a tetrameric structure. Isoelectric focusing of the $800-900 \mathrm{kDa} \mathrm{Ig}$ showed several bands between $\mathrm{pH} 5.5$ and $\mathrm{pH}$ 5.8. Mean Ig concentration in serum of 10 turbot was measured to $6.48 \mathrm{mg} / \mathrm{ml}$ (SD 5.4) using rocket immunoelectrophoresis. Low molecular weight antigen binding molecules were copurified with the dominating immunoglobulıns with an estimated MW of $500 \mathrm{kDa}$. Reducing SDS-PAGE of this fraction revealed molecules with MWs of 97, 79, 57, 29, and $27 \mathrm{kDa}$.
\end{abstract}

affinity purification; gel filtration; fish; rabbit anti turbot Ig.

\section{Introduction}

Immunoglobulins of teleosts are generally described as IgM-like tetramers composed of heavy and light polypeptide chains (Marchalonis 1977). However, some variation in the structure and properties of these fish proteins has been demonstrated. Evidence of low molecular weight Ig forms, dimers and monomers, in this vertebrate group has been presented (Clem \& McLean 1975, Lobb \& Clem 1981, Elcombe et al. 1985, Buchmann et al. 1992). In addition the existence of isotypes of heavy chains (Lobb \& Olson 1988) and light chains (Lobb et al. 1984) has been demonstrated. Of the numerous studies on humoral immune response in the teleost group only few and limited studies have been concerned with the immunoglobulins from flatfishes (Pleuronectiformes) (Cottrell 1977, Secombes et al. 1991, Al-Harbi \& Austin 1993). Therefore the present paper describes the isolation of serum immunoglobulin from turbot (Scophthalmus maximus) by affinity purifica- 
tion, its subsequent biochemical characterization and the generation of a monospecific rabbit anti turbot Ig serum.

\section{Materials and methods \\ Experimental animals}

Fourty turbots with body weights of 200 - 300 $\mathrm{g}$ were used in the experiments and kept under mariculture conditions in fiberglass ponds containing $8 \mathrm{~m}^{3}$ oxygenated seawater. Salinity was approximately $25 \mathrm{ppt}$ and water temperature increased from 10 to $18{ }^{\circ} \mathrm{C}$ during the immunization period. Before blood sampling the fish were anaestetized with benzocaine.

Rabbits for production of rabbit anti-turbot antisera were kept in $5000 \mathrm{~cm}^{2}$ cages and fed a standard laboratory animal diet. Before blood sampling, animals were sedated with fluanisonum $10 \mathrm{mg} / \mathrm{ml}$, fentanylum $0.2 \mathrm{mg} / \mathrm{ml}$ (Hypnorm, Janssen Pharmaceutica, Belgium).

\section{Immunization and blood sampling}

Specific antibodies to dinitrophenylated human serum albumin (DNP-HSA)(Sigma) were raised in turbots by intraperitoneal injection of $0.1 \mathrm{ml}$ of an emulsion of DNP-HSA and Freund's complete adjuvant (Statens Seruminstitut, Copenhagen, Denmark) corresponding to $366 \mu \mathrm{g}$ antigen/fish. Injections were repeated after 42 and 84 days using Freund's incomplete adjuvant (Sigma). Water temperatures were $10^{\circ} \mathrm{C}, 16^{\circ} \mathrm{C}$, and $18^{\circ} \mathrm{C}$ at first, second, and third immunization, respectively. Turbots were bled from the tail 33 days after the last immunization and the pooled blood samples were allowed to clot for $4 \mathrm{~h}$ at room temperature. After removal of the coagulum serum was collected by centrifugation at $3000 \mathrm{~g}$ for $20 \mathrm{~min}$ and stored at $-20^{\circ} \mathrm{C}$.

Two rabbits were immunized 3 times during a 2 months period by subcutaneous injections of an emulsion of equal volumes of purified turbot immunoglobulin solution and Freund's complete adjuvant in first immunization and Freund's incomplete adjuvant in boosters, corresponding to $100 \mu \mathrm{g}$ Ig per animal. Serum was prepared as described above.

\section{Purification of immunoglobulin}

Turbot serum was diluted 1:5 in phosphate

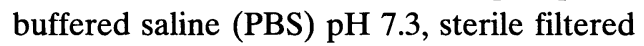
(Minisart, $0.2 \mu \mathrm{m}$ pore size), and loaded onto a column containing agarose coupled with dinitrophenylated bovine serum albumin (DNPBSA), (Mini-leak, medium activated, KemEn-Tec, Denmark). After extensive washing with $0.5 \mathrm{M} \mathrm{NaCl}$ in PBS protein bound to the column matrix was eluted with $50 \mathrm{mM}$ diethylamine (DEA) buffer, $\mathrm{pH} 11.6$, in $0.15 \mathrm{M} \mathrm{NaCl}$ and further purified by gel filtration in a Sephacryl-300 Superfine (S-300) or a Sephacryl400 High Resolution (S-400) (Pharmacia, Uppsala, Sweden) column eluted with PBS, $\mathrm{pH} 7.3$, containing $0.001 \%$ sodium azide. Concentrations of protein in collected fractions were determined by the bicinchoninic acid - copper(II) sulphate assay (BCA-1 kit, Sigma).

\section{$S D S-P A G E$}

Sodium dodecyl sulphate polyacrylamide gel electrophoresis (SDS-PAGE) was performed in a Mini Slab cell (Idea Scientific Company, Mn, USA) (Matsudaira \& Burgess 1978). Electrophoresis under reducing conditions was carried out in $10 \%$ gels (Laemmli 1970) and under non-reducing conditions in 3.0 or $5.0 \%$ gels (Weber \& Osborn 1969). After electrophoresis, gels were stained with Coomassie brilliant blue or subjected to immunoblotting (western blot).

\section{Western blot}

Proteins from turbot serum and gel filtered 
fractions were separated by SDS-PAGE and blotted onto nitrocellulose membranes in a semi-dry blotter (Kem-En-Tec, Copenhagen, Denmark) (Kyhse-Andersen 1984). Blocking and subsequent incubations were carried out at room temperature in a blocking buffer consisting of PBS containing $1.0 \%$ non-fat instant dry milk. Nitrocellulose filters were incubated with rabbit anti turbot antiserum diluted 1:200 - 1:51200, using a Convertible ${ }^{\mathrm{TM}}$ Filtration Manifold System (BRL Life Technologies, Md, USA), and thereafter peroxidase labeled swine anti-rabbit IgG (Dako, Glostrup, Denmark) diluted 1:2000. Between steps filters were washed 4 times in PBS containing $0.05 \%$ Tween 80 . Peroxidase activity was visualized with diaminobenzidine (DAB) tablets, $10 \mathrm{mg}$ (Sigma), dissolved in $40 \mathrm{ml} \mathrm{H}_{2} \mathrm{O}$ and added $20 \mu \mathrm{l} 30 \% \mathrm{H}_{2} \mathrm{O}_{2}$.

\section{Dot blot assay}

Ten $\mu$ l of DNP-HSA solution, $100 \mu \mathrm{g} / \mathrm{ml}$ in PBS, were added to nitrocellulose membranes using a Convertible ${ }^{\mathrm{TM}}$ Filtration Manifold System (BRL Life Technologies, Md, USA). Incubation with 2 fold dilution series of turbot immune and nonimmune sera, blocking and following steps were carried out as described above.

\section{Isoelectric focusing}

Isoelectric focusing was performed in agarose gels (IsoGel, FMC Bioproducts, Maine, USA) at $1500 \mathrm{~V}$ for $20 \mathrm{~min}$ according to the instructions of the manufacturer.

\section{Immunoelectrophoresis}

Crossed immunoelectrophoresis (CIE), Rocket immunoelectrophoresis (RIE) and fused rocket immunoelectrophoresis (FRIE) was carried out in $1 \%$ agarose (Litex HSA, Denmark) in Tris-Barbital buffer, $\mathrm{pH} 8.6$ ( $A x$ elsen 1983).

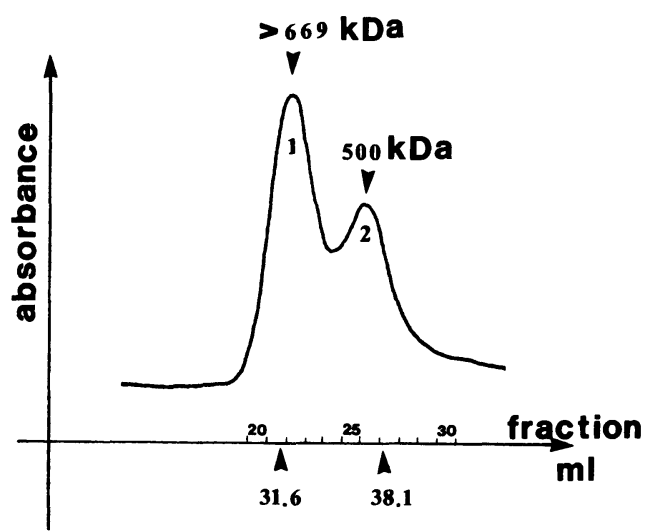

Figure 1. The UV-light absorbance profile of the S-300 filtration of the affinity purified turbot serum showing 2 peaks, corresponding to molecular weights of approxımately $>669$ and $500 \mathrm{kDa}$, respectively. Collected fraction numbers and $\mathrm{ml}$ eluate are indicated along the abscissa.

\section{Double diffusion precipitation}

Double diffusion precipitation test (Ouchterlony 1958) was carried out using $1 \%$ agarose (Litex HSA, Demnark) in Tris-Barbital buffer, $\mathrm{pH}$ 8.6.

\section{Results}

The response of the turbots to the hapten-carrier conjugate, DNP-HSA, was measured by both a double diffusion precipitation test and a dot-blot test. The double diffusion test showed a precipitation line with serum from the immunized fish and none with the serum from the controls.

The dot blot test revealed that pooled sera from non-immunized fish possessed a relatively high anti DNP-HSA titre, 1:128, but after 3 immunizations, the titre of pooled sera showed an increase to 1:512.

Antigen binding immunoglobulins were isolated by affinity chromatography on a DNP- 


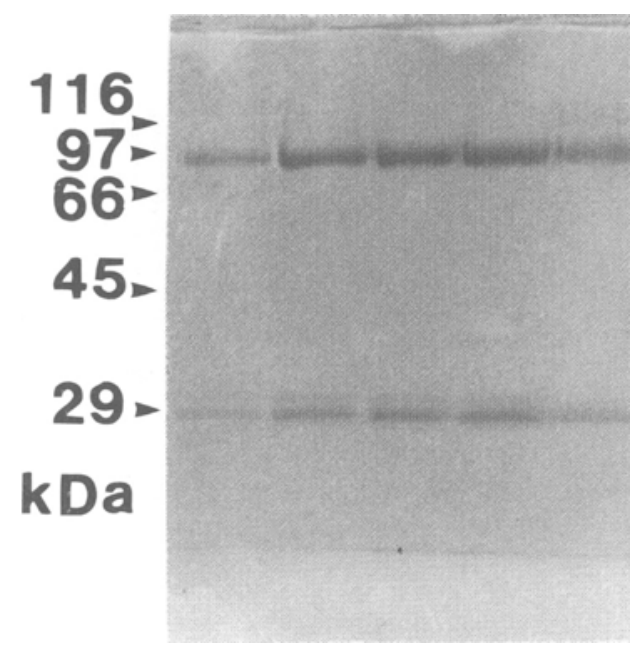

Figure 2A. SDS-PAGE of fractions from peak 1 run in a $10 \%$ polyacrylamide gel under reducing conditions showing 1 major band at $79 \mathrm{kDa}$ and $2 \mathrm{mi}-$ nor bands at $29 \mathrm{kDa}$ and $27 \mathrm{kDa}$. Lanes 1 - 5 correspond to fractions $20-24$ from Fig. 1 . Numbers to the left are molecular weight markers.

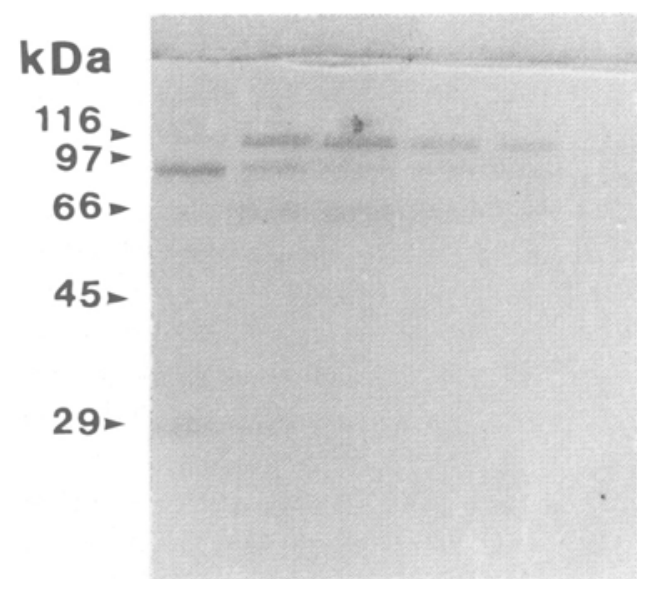

Figure 2B. SDS-PAGE of fractions from peak 2 run in a $10 \%$ polyacrylamide gel under reducing conditions containing an additional band at $97 \mathrm{kDa}$ and smaller amounts of a protein of $57 \mathrm{kDa}$. Lanes 1 -6 correspond to fractions $25-30$ from Fig. 1.

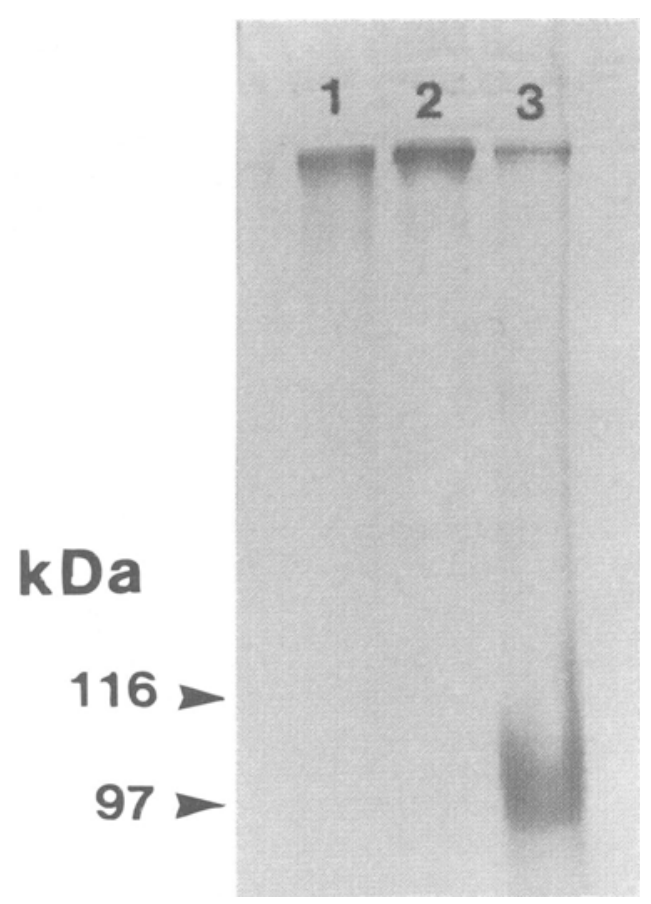

Figure 3A. SDS-PAGE run under non-reducing conditions with $3 \%$ stackıng gel and $5 \%$ separation gel. Lane 1: purffied salmon Ig, lane 2: fractions from peak 1, and lane 3: fractions from peak 2.

No major proteins were able to penetrate the gel matrix, except a protein in lane 3 of approximately 100 $\mathrm{kDa}$.

BSA column. Proteins non-specifically adsorbed to the column were removed by thorough washing with $0.5 \mathrm{M} \mathrm{NaCl}$ in PBS before elution with DEA-buffer. The eluate was pooled and applied onto a S-300 column. The $280 \mathrm{~nm}$ absorbance profile of the gel filtrate revealed 2 closely positioned peaks corresponding to MW's of $>669 \mathrm{kDa}\left(\mathrm{V}_{\mathrm{o}}\right)$ and approximately $500 \mathrm{kDa}$ (Fig.1). When collected fractions were subjected to SDS-PAGE $10 \%$ polyacrylamide under reducing conditions the first peak displayed 1 major band of 79 and 2 minor bands of $29 \mathrm{kDa}$ and $27 \mathrm{kDa}$. The 27 $\mathrm{kDa}$ protein was more dominant than that of 


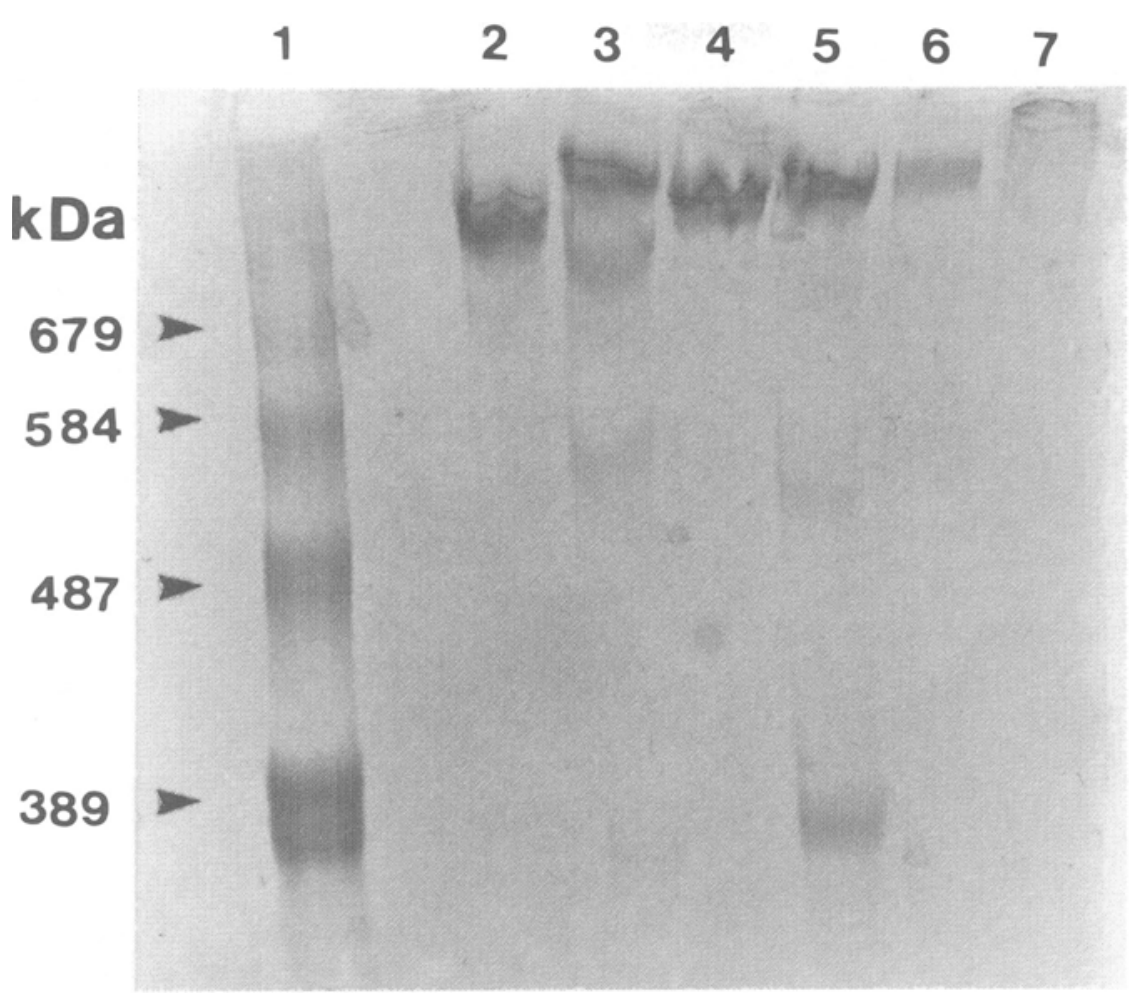

Figure 3B. SDS-PAGE run under non-reducing conditions in a 3\% separation gel. Lane 1: molecular weight markers, lane 2: purified salmon Ig, lane 3: purified rainbow trout Ig, lane 4: fractions from peak 1, lane 5: fractions from peak 2, lane 6: a small fraction from peak 2, lane 7: purıfied IgM from mink (MW approximately 1000 $\mathrm{kDa})$.

the $29 \mathrm{kDa}$ protein (Fig.2A). The second peak contained the same structures but also an additional major band of $97 \mathrm{kDa}$ and small amounts of protein of $57 \mathrm{kDa}$ (Fig.2B).

No proteins of the first peak fraction were able to penetrate into a 5\% SDS-PAGE gel run under non-reducing conditions, but the second peak was shown to contain a protein of $97 \mathrm{kDa}$ and a non penetrating protein (Fig $3 \mathrm{~A})$. The proteins with the molecular weights of 79,29 and $27 \mathrm{kDa}$ were not demonstrated under these conditions.

SDS-PAGE in $3 \%$ gels run under non-reducing conditions, showed a protein from peak one of approximately $850 \mathrm{kDa}$, while the second peak contained proteins of $850 \mathrm{kDa}$ and $400 \mathrm{kDa}$. In addition trace amount proteins of $500 \mathrm{kDa}$ and an unseparated protein fraction with MW below $205 \mathrm{kDa}$, represented by the gel front, were found in peak two (Fig 3B). Rabbits were immunized with protein from fractions containing only the high molecular weight component from the first peak. The high molecular weight protein concentrated to $1700 \mu \mathrm{g} / \mathrm{ml}$ by ultrafiltration (Centriprep-30 Concentrators, Amicon Division, Beverly, MA, USA) was applied onto a Sephacryl S-400 column. The results indicated a 


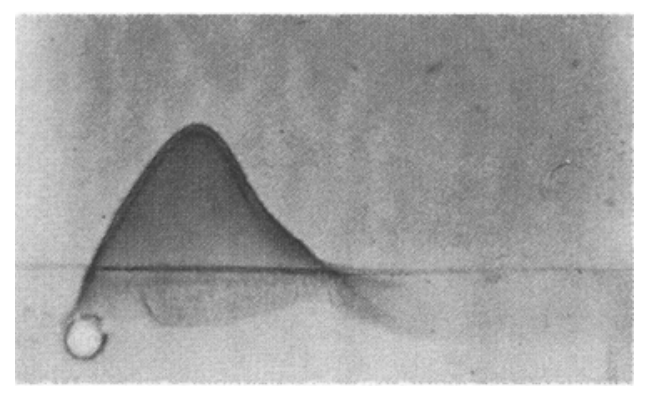

Figure 4. The reactivety and specificity of the rabbit anti turbot antiserum as judged by CIE. Total turbot serum was run in first dimension, and electrophoresed into the second dimension gel containing rabbit anti turbot antisera. The anode is to the right in the first dimension electrophoresis and at the top in the second dimension.

molecular weight of approximately $850 \mathrm{kDa}$. Isoelectric focusing of the high molecular weight proteins from peak one revealed several bands ranging between $\mathrm{pH}$ values of 5.5 and 5.8.

The reactivity and specificity of the rabbit anti turbot antisera was tested by CIE. A single precepitation arch with a double contour appeared (Fig. 4)

Turbot serum fractions collected from the S400 gel filtration column were subjected to FRIE and RIE. A major precipitation arch and rocket occurred at an elution volume corresponding to $\mathrm{MW}$ of 850 - $900 \mathrm{kDa}$ (Fig. 5).

In the western blot of total turbot serum, rabbit antisera in dilution below 1:1600 reacted to several bands, but 3 major bands were seen at 150,79 and $57 \mathrm{kDa}$, and 2 distinct bands at 29 and $27 \mathrm{kDa}$. No reaction was noticed against the $97 \mathrm{kDa}$ protein.

When rabbit antisera were diluted 1:3000 only 3 bands appeared on the blot, corresponding to $79 \mathrm{kDa}$ and 27-29 kDa bands and in dilution 1:6400 only the $79 \mathrm{kDa}$ band reacted (Fig 6A). In western-blot made on a purified immunoglobulin fraction, specific reaction was re-

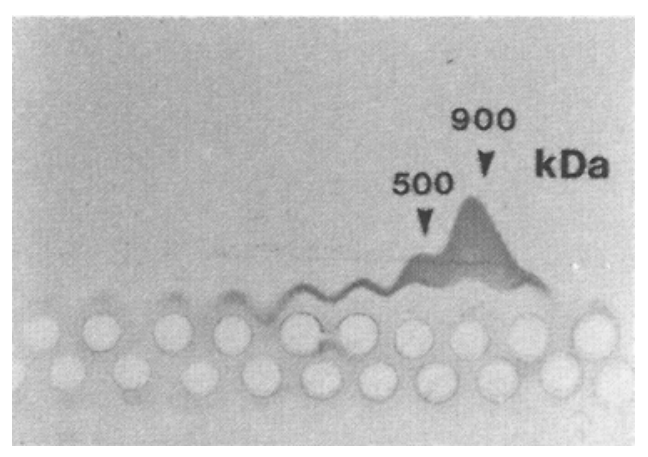

Figure 5. Fractions of turbot serum collected from the S-400 column subjected to FRIE demonstrated a monospecific rabbit anti turbot Ig antiserum with 2 peaks. The gel contained rabbit antı turbot Ig serum. Anode at the top.

corded against 2 protein bands at $79 \mathrm{kDa}$ and 27 kDa (Fig. 6B).

To analyse if the antiserum had affinity to the proteins from the S-300 fraction peak two, these proteins were investigated by a dot blot test. This revealed a positive reaction in dilutions up to $1: 12800$.

The Ig concentration in turbot serum was measured by RIE. Serum from 10 turbot contained a mean of $6.48 \mathrm{mg}$ immunoglobulin per $\mathrm{ml}$, standard deviation (s.d.) $\pm 5.40 \mathrm{mg} / \mathrm{ml}$, while total serum protein contents measured by the BCA test gave a mean of $27.0 \mathrm{mg} / \mathrm{ml}$, s.d. $\pm 9.2 \mathrm{mg} / \mathrm{ml}$.

\section{Discussion}

As has been detected in other teleosts (Marchalonis \& Warr 1978, Vilain et al. 1984, Buchmann et al. 1992) serum of non-immunized turbot contains natural antibodies to DNP, but anti-DNP-HSA titre in turbot serum rose after repeated immunization with DNP conjugated to HSA. The following affinity-purification of antigen-specific antibodies from immune sera on a DNP-agarose column 


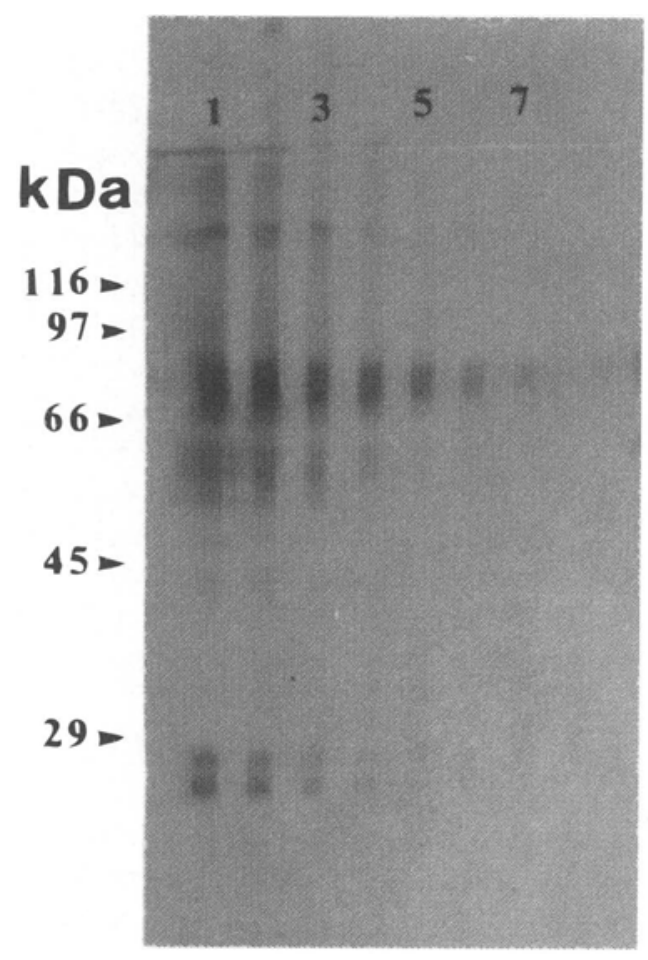

Figure 6A. Western blot of total turbot serum showed a reaction of the rabbit anti turbot antiserum to several bands depending on the dilution.

The dilution were twofold starting with 1:200 (lane 1) unt1l 1:51200 (lane 9).

recovered 2 groups of proteins with the dominating molecular weights of $800-900 \mathrm{kDa}$ and $500 \mathrm{kDa}$ respectively, as judged by $\mathrm{S}-400$ and S-300 gelfiltration and non reduced SDSPAGE. Reduced SDS-PAGE analysis of these fractions showed that the former and dominating fraction was composed of disulphide linked heavy (79 kDa) and light (27 and $29 \mathrm{kDa}$ ) chains, whereas the low molecular weight fraction also contained an additional protein band of $97 \mathrm{kDa}$ and small amounts of protein of $57 \mathrm{kDa}$. As the high molecular weight protein fraction corresponded to the classical IgM-like immunoglobulin described



Figure 6B. Western blot of purified turbot Ig showed specific reaction of the rabbit anti turbot antiserum to the heavy chain in dilutions up to 1:3200 and to a light chain in dilution 1:200. Dilutions were twofold starting with 1:200 (lane 1).

from teleosts (Shelton \& Smith 1970, Pilstrom \& Peterson 1991) rabbits were immunized with this putative turbot immunoglobulin which resulted in the generation of a monospecific rabbit antiserum. Western blot analysis demonstrated this antiserum in a dilution of 1:6400 to react specifically with a $79 \mathrm{kDa}$ turbot serum protein corresponding to the heavy chain of the immunoglobulin. The finding of 2 putative light chains of 27 and $29 \mathrm{kDa}$, respectively, suggest the presence of Ig light chain isotypes in turbot. The western blot also showed a reaction of the rabbit anti turbot serum to these 2 proteins in dilutions up to 
1:3000. Isotypes of light chains have previously been reported in the channel catfish (Ictalurus punctatus) (Lobb et al. 1984). The isoelectric point of the high-molecular weight fraction was found in the range between $\mathrm{pH}$ 5.5 and 5.8 which is in accordance with values for Igs from salmon (Håvarstein et al. 1988) and cod (Pilström \& Peterson 1991). Also the concentration of immunoglobulin in the serum of turbot $(6.48 \mathrm{mg} / \mathrm{ml})$ was of a magnitude normally detected in teleosts (Israelson et al. 1991). The recovered high molecular weight immunoglobulin is thus readily interpreted as a tetramer consisting of disulphide linked heavy and light chains but the nature of the low molecular weight fraction seems more complicated. The monospecific rabbit anti turbot serum also reacted with this fraction as shown from both dot blot analysis and FRIE and the presence of disulphide linked protein bands of $79 \mathrm{kDa}$ and $27 \mathrm{kDa}$ and $29 \mathrm{kDa}$ in this fraction indicates the presence of immunoglobulin in this fraction. The amount of proteins of $800 \mathrm{kDa}$ in the unreduced SDSPAGE $3 \%$ polyacrylamide from peak 2 must be interpreted as residues of Igs from peak 1 due to tailing from the gel filtration column. Teleost immunoglobulins have not invariably been shown to consist solely of tetramers as also the presence of monomer (Clem \& McLean 1975, Elcombe et al. 1985) and dimer (Lobb \& Clem 1981, Buchmann et al. 1992) molecules have been suggested. Investigations of immunoglobulins from flatfishes have only suggested high molecular weight forms (Cottrell 1977, Secombes et al. 1992, Al-Harbi \& Austin 1993) but the $400 \mathrm{kDa}$ protein recovered from turbot serum in unreduced SDSPAGE in $3 \%$ polyacrylamide gels in the present study could be interpreted as a dimer Ig molecule in accordance with the S-300 gelfiltration investigations. However, the presence of the additional $97 \mathrm{kDa}$ and $57 \mathrm{kDa}$ band in the low molecular weight fraction does not conform with a classical description of immunoglobulins. The function and properties as well as their possible association with immunoglobulins are at present unknown. Similar proteins copurified with putative low molecular weight antibodies were tentatively interpreted as a secretory component ( $L o b b$ \& Clem 1981) or suspected to be a complement related factor (Buchmann et al. 1982). The molecular weights of the alpha and betachains of complement factor C3 in different vertebrates have been reported to range from 107-119 and 64-83 kDa respectively (Alsenz et al. 1992) thus the possible complement related nature of the copurified proteins from turbot should be further elucidated.

\section{Acknowledgements}

This work was supported by grants from the Carlsberg Foundation and The Danish Agricultural and Veterınary Research Council grant no. 13-4710-1 and 13-4508-1 NMP.

\section{References}

Al-Harbı AH, Austin B: Purification of macroglobulıns from the serum, and skın and gut mucus of turbot (Scophthalmus maximus L.) immunized with lipopolysaccharide (LPS) from a fish-pathogenic cytophaga-like bacterium (CLB). Bull. Eur Ass. Fish Pathol., 1993, 13, 40-44.

Alsenz J, Avlla D, Huemer HP, Esparza I, Becherer $J D$, Kinoshita T, Wang Y, Oppermann S, Lambris $J D$. Phylogeny of the third component of complement, C3: Analysis of the conservation of human $\mathrm{CR} 1, \mathrm{CR} 2, \mathrm{H}$, and $\mathrm{B}$ binding sites, concanavalin $\mathrm{A}$ binding sites, and thiolester bond in the C3 from different species. Dev. comp. Immunol. 1992, 16, 63-76.

Axelsen NH: (ed.). Handbook of immunoprecipitation-1n-gel techniques. Scand. J. Immunol. 1983, 17, suppl. no. 10.

Buchmann K, Østergaard L, Glamann J. Affinity purification of antigen-specific serum immunoglobulin from the European eel (Angulla angulla) Scand. J. Immunol. 1992, 36, 89-97. 
Clem LW, McLean WE Phylogeny of immunoglobulin structure and function. VII. Monomeric and tetrameric immunoglobulin of the margate, a marine teleostfish. Immunology 1975, 29, 791-799

Cottrell $B$ The immune response of plaice (Pleuronectes platessa L.) to the metacercariae of Cryptocotyle lingua and Rhipidocotyle johnstonet. Parasitol. 1977, 74, 93-107.

Elcombe BM, Chang RJ, Taves CJ, Winkelhake JL. Evolution of antibody structure and effector functions. comparative hemolytic activities of monomeric and tetrameric IgM from rainbow trout, Salmo gaırdnerı Comp. Biochem. Phys1ol. 1985, 80B, 697-706.

Håvarstein LS, Aasjord PM, Ness S, Andresen C. Purification and partial characterızation of an IgM-like serum immunoglobulın from salmon (Salmo salar) Dev. comp. Immunol. 1988, 12, 773-785.

Israelsson O, Petersson A, Bengtén E, Wiersma EJ, Andersson J, Gezelius G, Pllstrom L· Immunoglobulın concentration in Atlantic cod, Gadus morhua L., serum and cross-reactivity between anti-cod-antıbodies and immunoglobulins from other species. J. Fish Biol. 1991, 39, 265-278.

Kyhse-Andersen J. Electroblottıng of multıple gels: a simple apparatus without buffer tank for rapid transfer of proteins from polyacrylamide to n1trocellulose. J. biochem. biophys Meth. 1984, 10, 203-209.

Laemmlı UK Clevage of structural proteins durıng the assembly of the head of bacteriophage T4. Nature 1970, 227, 680-685.

Lobb CJ, Clem LW. Phylogeny of immunoglobulın structure and function. XI Secretory immunoglobulins in the cutaneus mucus of the sheepshead, Archosargus probatocephalus Dev. comp Immun 1981, 5, 587-596.

Lobb CJ, Olson MOJ. Immunoglobulin heavy $\mathrm{H}$ chain isotypes in a teleost fish. J. Immunol. 1988, 141, 1236-1245.

Lobb CJ, Olson MOJ, Clem LW. Immunoglobulin light chain classes in teleost fish. J. Immunol. 1984, 132, 1917- 1922.

Marchalonis JJ Emergence of IgM 1mmunoglobulins. In: Immunity in evolution, p.74, Harward University Press, Cambridge, Massachusetts, 1977.

Marchalonis JJ, Warr GW. Phylogenetic origins of immune recognition: naturally occurring DNPbinding molecules in chordate sera and hemolymph. Dev. comp. Immunol. 1978, 2, 443-460.
Matsudaira PT, Burgess DR SDS microslab linear gradient polyacrylamide gel electrophoresis. Anal. Biochem. 1978, 386, 386-396.

Ouchterlony $O$. Diffusion-1n-gel methods for immunological analysis In: P Callos (ed.). Progress in Allergy, 1958, vol. V, p 1. Karger, Basel

Pllstrom L, Petersson A - Isolation and partial characterization of immunoglobulın from $\operatorname{cod}(\mathrm{Ga}$ dus morhua L.). Dev comp. Immunol 1991, 15, 143-152.

Secombes CJ, White A, Fletcher TC, Houlthan DF. The development of an ELISPOT assay to quantıfy total and specific antıbody-secreting cells in dab (Lımanda lımanda (L)) Fish and Shellfish Immunol. 1991, 1, 87-97.

Shelton $E$, Smuth $M$ The ultrastructure of carp ( $C y$ prinus carpıo) ımmunoglobulın: a tetrameric macroglobulın. J molec. Biol. 1970, 54, 615-617.

Vilain C, Wetzel M-C, Pasquier LD, Charlemagne J. Structural and functional analysis of spontaneous ant1-nitrophenyl antibodies in three cyprinid fish species: carp (Cyprinus carpıo), goldfish (Carassius auratus) and tench (Tinca tinca) Dev. comp. Immunol. 1984, 8, 611-622.

Weber K, Osborn $M$ The reliability of molecular weight determinations by dodecyl sulfate-polyacrylamide gel electrophoresis. J biol Chem. $1969,244,4406-4412$

\section{Sammendrag}

Oprensning og karakteriserıng af et IgM-lıgnende immunglobulın fra pighvar (Scophthalmus maxımus L.)

I alt blev 40 pighvar immuniseret 3 gange 1 løbet af en 3 måneders perıode med DNP-HSA, hvorefter sera blev opsamlet og poolet Specifikke immunglobulıner blev affınitets-oprenset på en agarose søjle med immobiliseret DNP-BSA og yderligere oprensning blev foretaget ved hjælp af gel filtrerıng. Størrelses chromatografı og ureduceret SDS-PAGE indicerede en MW på ca. $850 \mathrm{kDa}$ af det domınerende antigenbindende protein fra pighvar sera. $\mathrm{Re}$ duceret SDS-PAGE viste, at denne fraktion bestod af en tung kæde med MW på $79 \mathrm{kDa}$ samt to lette kæder på henholdsvis 27 og 29 kDa, bundet sammen med svovlbındinger. Det dominerende pighvar immunglobulin synes derfor at være en tetramer struktur. Isoelektrısk focuserıng af dette protein viste adskillige bånd med en pH værdı fra 5,5 t1l 5,8. Middelværdien af ımmunglobulın-koncentrationen 1 serum fra 10 pighvar blev målt til $6,48 \mathrm{mg} / \mathrm{ml} \mathrm{med} \mathrm{en}$ 
standard afvigelse på $\pm 5,4 \mathrm{mg} / \mathrm{ml}$ ved hjælp af raket immunelektroforese.

En fraktıon af antıgenbindende molekyler med en lavere molekylvægt blev oprenset sammen med det dominerende immunglobulın. Reduceret SDSPAGE af denne fraktion viste, at den indeholdt proteiner med molekylvægte på henholdsvis 97, 79, 57, 29 og $27 \mathrm{kDa}$.

(Recelved May 19, 1993; accepted September 21, 1993).

Reprints may be requested from: K. Pedersen, Department of Microbiology, Section of Fish Diseases, Royal Veterınary and Agricultural Unıversıty, Bulowsvej 13, DK-1870 Frederıksberg C, Denmark. 